\title{
Multiples Transgressions: Sexuality and Spirituality of Moroccan Diaspora in the Works of Tahar Ben Jelloun
}

\author{
Richard Oko Ajah, $\mathrm{PhD}$ \\ Department of Foreign Languages, University of Uyo, Nigeria
}

\begin{abstract}
Sexuality and spirituality constitute a superstructure on which Ben Jelloun's plots are mostly founded. Reading his writing as gay and missiological discourse permits us to understand that Ben Jelloun's "multiple" transgressions enable him to challenge Eurocentric and traditional epistemologies, thereby deconstructing sexuality and spirituality in his Islamic society. Focusing on the Moroccan Diaspora and prospective migrants, it can be said that Ben Jelloun's homosexuality and spirituality are not attitudinal, but commodified and commoditised, thereby leading to sexual and spiritual ambivalence of diasporic consciousness.
\end{abstract}

Keywords : Ben Jelloun, Gay discourse, Migrant writing, Missiology, Transgressive sexuality

\section{INTRODUCTION}

Transgressive concepts such as gay and lesbianism have emerged in recent discourses of sexuality amidst domestication of feminism and its deconstructive notions. In the writing of Ben Jelloun, his literary world shows a vivid representation of these emerging sexual concepts and their relationship with the Maghrebian woman and her society at large. The writer creates a web of relationship between patriarchy and Islam, struggling to deconstruct and reconstruct those religious beliefs that undermine the liberation of Moroccan women in particular. Sanaa Benmessaoud ${ }^{1}$ and Salah Moukhlis ${ }^{2}$ unanimously agree that Ben Jelloun and his literary intention are considered transgressive and blasphemous, especially by Islamic conservatives who uphold the sacredness of Islamic doctrines and the impossibility of their transformation. To worsen it all, the writer juxtaposes Western religious consciousness with magic realism and mythology, in an attempt to write back to the European centre and challenge Eurocentric epistemologies. However, Jellounian reconstruction of sexuality, consciously or unconsciously, is not without its consequential crisis that casts recent sexuality and spirituality with clouds of ambivalence among Moroccan Diaspora in Europe. We understand that Ben Jelloun's homosexuality and spirituality are not attitudinal, but commodified and commoditised; both are subjected to processes of negotiation as strategy of diasporic survival. This commercial negotiation of attitude informs the ambivalence that characterises sexuality and spirituality in Ben Jelloun's migrant writing that transgresses social orders.

Transgressive writing challenges hegemony and dismantles metanarratives, thereby subverting historical and social orders. Ben Jelloun engages in 'multiple' transgressions because his writing deconstructs the knowledge of sexuality, spirituality and spatiality. In addition to his Islamic feminism, the writer presents homosexuality as an alternative of heterosexuality in local and foreign spaces as a way of blurring the boundaries of gender though homosexuals still undergo societal segregation because of religious perception. Like sexuality, religion is however presented as a product of social negotiation, a passport for actualisation of ephemeral dream in an exotic space that is also transgressed through clandestinity or illegal border crossing. The fragmented identity of immigrants makes them lose religious values and open to contradictory religious beliefs, becoming secularised in their convictions. In his writing such as Les Yeux baissés (1991), Labyrinthe des sentiment (1999), Partir (2006) and Au Pays (2009), Ben Jelloun blurs the hegemonic boundaries of gender, religion and space.

\section{REPRESENTATION OF SEXUALITY}

No literary world as painted by writers is complete without the representation of woman and her paradigmatic relationship with men and other women or vice versa. In essence, women remain at the epicentre of plots of Ben Jelloun's novels which become what Grace C. Okafor ${ }^{3}$ calls a literature of duality whereby male and female are realistically portrayed because African societies are heterosexual ${ }^{4}$. His works also unveil the heterosocial and homosocial power relations that structure Moroccan society both in domestic or diasporic spaces. In Ben Jelloun's travel writing, both male and female sexes are seen in existential paradigmatic relationships that are in most cases culturally and socioeconomically negotiated and mediated. The writer represents sexuality "in a manner particularly reflective of man's problematic interpersonal relations, especially relations between men and women and between the society and the individual" . He beams his literary 
searchlight on the generational conflicts between the old and the young, the traditional and the modern, and the religious and the secular, emanating from African patrilineal family which "is a structure where the father is the absolute head of the family whose authority over his wife (wives) and children is culturally sanctioned" 6 . Female children, unlike their submissive and domesticated mothers, confront the authority of fathers who bemoan the evils of civilisation and modernity in foreign lands.

In Ben Jelloun's works, sexuality politicises patriarchy, challenging its hegemony and biological gender hierarchies because both private and public spaces are now democratised and demythologised. The novels portray Moroccan women majorly in urban areas, symbolic of modernity, social opportunity and social mobility. With the collapse of closed and open spaces, Jellounian feminine characters now show, as well, obsessions for migration to Europe, a challenge to a migratory activity that was "predominantly male, at least in its initial phrases" . As we shall practically see, social categories such as class, gender, sexuality and race are now taken for granted, no longer given or fixed but rather they are understood as socially produced through processes of negotiation and contestation and as such are recognised to be multiple and fluid, according to Gill Valentine ${ }^{8}$. Such deconstructive sexuality leads to sexual transgressions of biological and traditional paradigms and systematic violation of Islamic religious beliefs in Ben Jelloun's works. Although all social categories are represented in his writing, the plots of these works are structured differently. Labyrinthe des sentiments (1999) and Partir (2006) paint the ugly images of Moroccan youth (male and female) and its struggle for a better life in Italy and Spain. Both novels justify their journeys which inadvertently end up shaping their sexuality and sensibility. Contrarily, Les Yeux baissés (1991) and Au Pays (2009) chronicle patrilineal family system, paternal authority and its challenge by immigrant male/female children of the immigrant patriarchs in France.

In Labyrinthe des sentiments and Partir, the writer focuses on Wahida (female) and Azel (male) respectively. Both protagonists are unemployed trained lawyers, disillusioned by the Moroccan corrupt society and obsessed with migration to Europe for greener pastures. Wahida and Azel are united by fate and feeling that succeed in shaping their sexuality and its unforeseen ambiguity. Wahida is confronted with social realities after the death of her breadwinner mother. With an uncaring polygamous father and being raised by an abusive stepmother, she is forced into prostitution at fifteen in the Moroccan town of Casablanca. The young girl learns rapidly the rudiments of her trade for which she has no love. She has no alternative either because of domestic responsibilities. Representational of womanhood, Wahida says:

Et nous, the femmes, nous devons subir cet étalage de misère pour oublier une autre misère, nous prenons des risques, nous acceptons n'importe quoi, parce que nous savons qu'au bout de la nuit, dans le taxi qui nous ramènera dans notre bidonville, nous froisserons les billets qui permettront au petit frère d'aller au lycée, à la petite sœur de s'acheter une jolie robe, à la tante de payer les médicaments pour le cœur. Nous comptons les billets et nous n'en tirons aucune fierté. ${ }^{9}$

And we, women, must undergo such display of misery in order to forget another misery, we take some risk, we accept anything, because we know that each night, in the taxi that will take us back to our shantytown, we will crumple banknotes that will enable a younger brother to go to high school, a younger sister to buy a beautiful dress, an aunty to procure heart medication. We count the banknotes with no iota of pride (My Translation).

Wahida displays images of sorrow that characterises the fate of the Moroccan womanhood. Her words are overt denunciation of patriarchal structures and of governmental irresponsibility that is defined by her inability to cater for her younger generation. With her sexual exposure as a prostitute, she only knows two faces of commercialised and customised love that conditions heterosexual relationship in Casablanca and Italy where she relocates to with the help of M. Samir who could be rather regarded as a pimp. It is in Naples that Wahida meets the exilic poet Gharib.

A middle-aged man who maintains a mystical and amorous relationship with Naples, what he calls "un amour ambigu", Gharib visits Ravello as a romantic and touristic space where he reunites mysteriously with the spirit of his dead lover, Gazelle who keeps haunting his dreams and thoughts since April 24, 1967. Thirty years passed, the wounds of the loss of Gazelle remain unhealed, even with balm of new love for Wahida. The new relationship goes with air of mystique that makes the beautiful Moroccan lady both available and impossible for Gharib's consumption. Wahida understands sexual intercourse as an expression of heterosexual love, but the poet envisages and experiments sexual purity in man-woman relationship. His love for Wahida is a "histoire d'amour platonique, histoire sans sexe, sans trop de complications." ${ }^{10}$ [story of platonic love, story of no sex, of no much complications], though he oscillates between contradicting opinions of desire for and resistance to Wahida's eroticised female body. The novels achieves denouement with ambiguous disillusionment of both 
partners. The object loved cannot be possessed. Like Wahida, Azel suffers more ambiguous sexuality before and after his journey to Spain.

The jobless lawyer relocates to Spain with the help of a homosexual partner. His gay escapades are premised on mutually unwritten negotiation and its socioeconomic gains that he derives from Miguel in Morocco and in Spain, yet he can be described as a heterosexual as Azel enjoys sexual intercourse with his numerous girlfriends including Siham and Soumaya. This explains why his purported impotency troubles and traumatises him to confirm Ben Jelloun's obsession for virile and sterile masculinity which Lahoucine Ouzgane $^{11}$ analysed in his work. In Partir $^{12}$, young girls are also free as young boys/men, engaged in menial jobs (Kenza, Malika) and prostitution (Siham, Soumaya, Khaddouj and her girls). Benmessaoud ${ }^{13}$ collaborates that the stereotyped representation of Arab women as uneducated and oppressed sexual objects emanates from The Nights. In the book review of Liberating Shahrazad, Benmessaoud underlines the influence of the classic The Night on Ben Jelloun and affirms that the writer has been fiercely criticised for self-orientalising and reinforcing centuries-old orientalist stereotypes of victimised Arab women. Admittedly a handful of women in Partir can be classified as victimised; but Ben Jelloun surpasses this primordial representation of womanhood by showing how laborious women such as Lalla Zohra, Azel's mother, assume paternal responsibilities to assure that his son becomes a lawyer. She is an illiterate, yet "suivait tous les soirs les informations à la television. Elle avait appris les chiffres pour pouvoir téléphoner." [was following televised news every evening. She had learnt numerals to be able to use telephone]. Educationally handicapped, the traditional Lalla Zohra overcomes such social barriers and penetrates a space exclusively reserved for the modern.

Other younger Moroccan women such as Siham, Soumaya and Kenza migrate to Europe to seek the proverbial greener pastures. They struggle with their troubled sexuality that gradually defines their subjective identity. Soumaya is a Moroccan, abandoned by her Asian husband; Siham works as a nanny of a handicapped girl for an interracial couple and Kenza is employed in Cruz Roja, Barcelona. All these Moroccan can be called liberated women in the sense that they are not relegated to the domestic background because "most cultures see the woman as the weaker sex who is created to take care of domestic chores while the man plays the role of the head and provider of security and food for the family."15 Ben Jelloun's typical Moroccan woman, though suffering from common socioeconomic quagmire, is no longer, according to Ephrem Sambou "16 "comparée à un objet" [compared to an object] nor "apparaît alors comme du matériel au service ou à la disposition de l'homme qui en use sans scrupules" [appears then as material in the service or disposition of man who uses it unscrupulously]. Unlike Harem culture that conditions the feminine displacement, these feminine characters are highly deterritorialised, so become social occupants of multiples trans/national spaces. Although Azel, Kenza, Siham and Soumaya succeed in migrating to Spanish territory, but unfortunately they find out bitterly that Spain is not "paradis terrestre" [earthly paradise], their "migrant bovarysm" (Pireddu) dissolves into mortifying bombshell. Azel ends up losing his life; Kenza returns to Morocco as civil right activist; and Siham and Soumaya are appropriated to silence.

In Les Yeux baissés ${ }^{17}$ and $A u$ Pays $^{18}$, old generation migrants are juxtaposed with new generation immigrant children. Masculine and feminine genders are given maximum preeminence, though it is the female protagonist Fathma who narrates her story in the first novel while Mohamed, the traumatised immigrant patriarch, appears to be reading the diary that individualizes partly the narrative and an omniscient narrator intervenes intermittently and drives the engine of the novel to denouement after the death of the patriarch. The writer shows Fathma's evolution from infancy to adolescence, from ignorance to knowledge and from a Moroccan village to a suburb in France, typical of a Bildungsroman that deals with the formative education of a character. As opposed to her timid and passive traditional mother, this female protagonist shows infantile militancy and adolescent rebellion. She constitutes Ben Jelloun's novel conceptualisation of Moroccan woman who despite her shortcomings, overcomes paedophilia, conquers illiteracy and acquires western education. It is in the character of Fathma that the writer contests and reconceptualises the age-long patriarchal comparative conditioning of woman as mentally retarded. From the role of a shepherdess who desired Islamic education exclusive to young masculine Muslims in a rural community, she becomes literate, educated, illumined and liberated in France. Unlike her mother, Fathma does not fear Slima, the sorceress and witch who ends up killing Driss, her only brother. She is the only person that has the courage to tactfully confront her villain aunty who, before their departure to France, was a torn in their flesh. With inevitable salient qualities, she becomes an adventurer-heroine of the novel.

Slima the enchantress engages in devilish and destructive machinations that bring grief and groaning to her husband, Fathma and her family, and other numerous women in the novel. Her activities culminate in the death of her brother's only son, Driss. The author uses the character of Slima or Khadouj to show that feminine oppression does not only emanate from patriarchy, but also from matriarchy. It unveils the fact that women can be axe-men of womanism ${ }^{19}$. Patriarchal orders and ordering are not overtly figured in Les Yeux baissés, as the unlocking of the hidden treasure whose key is sealed in Fathma, and its ceremonies are the complementary responsibility of both men and women in the village. After years of sojourn in France, her decision to return to 
Morocco to fulfill her destiny is patriotic and opportunistic; she desires to confirm the veracity of the myth of hidden treasure. Ouzgane opines that her failure to unlock the treasure and liberate the village from perennial lack amounts to the fact that real salvation cannot be expected from a woman, an indictment to the writer, Ben Jelloun. Such hasty assumption and generalisation refuses to realize that Fathma is only metonymic of her community who fails to know that the key (solution) to their lack is buried in them. The writer attempts to demythologise and demystify a traditional Moroccan community that is given to superstitions and stereotypes, instead of taking proactive Marxist measures to solve their collective dilemma. At the discovery of water and its festivities, the narrator comments that the hands who labored for water " sont vaincu les legendes"20 [have overcome legends] because the people "enfin, sont devenus travailleurs de la terre" [at last have become workers of the land]. An epistolary information affirms that "les femmes travaillent plus que les hommes",22 [women work more than men].

In $A u$ Pays, the author focuses on the patriarch Mohamed and his family in France where his children are born and bred. Mourad, Rachid, Jamila, Othmane and Rekya construct their subjective sexualities and identities despite the disappointment of Mohamed. In acquiring westernised education, Jamila and Rekya secure cultural password to access masculine spaces. Despite paternal opposition to interreligious marriage, both Mourad and Jamila are married to Christian European woman and man respectively, redefining sexuality and its stereotypical social conditionings. Ben Jelloun uses father-children generational conflict to deconstruct patriarchy, masculinity and its strongholds on human society, while underlining the influence of western education on immigrant children of Moroccan origin in France. Mohamed maintains his grips on his traditional wife, loses his grips on his new generation children and loses as well paternal cult that patriarchy bestows on him. He ends up as a traumatised and victimised father, dying in a palatial mansion that he only shares with his wife in absence of most cherished children.

Ben Jelloun presents sexuality as problematic and transgressive in his travel narratives; they project a crisis-ridden sexuality and identity, full of fluidity and flexibility that challenges its primordial stereotypes. His literary universe is representational of a heterogeneous and heterosexual African society that outlaws transgressive sexualities which are socially and culturally Othered.

\section{CRISIS OF SEXUALITY}

Wendy Mckenna and Suzanne Kessler ${ }^{23}$ admit that gender and its boundaries are blurred today. That explains why social categories such as class, gender, sexuality and race are no longer taken for granted as given or fixed but rather are now understood as socially produced through processes of negotiation and contestation and as such are recognized to be multiple and fluid. For David Morgan ${ }^{24}$, gender transgression challenges masculinity and patriarchy whose crisis is attributed to the rise of feminism. However, masculinity and femininity are enmeshed in crisis, occasioned by cultural fluidity and deconstruction of metanarratives. Inherent in transgressive notions such as transgender, bisexuals, lesbians, gays among others is the (re)construction of attitude that is socially atypical to biological paradigms. Etoke ${ }^{25}$ is partly right to assume that female homosexuality is never openly addressed in African literature; rather it works as a narrative lure because $75 \%$ of African nations outlaw what other nations consider to be a legitimate ${ }^{26}$. Christianity and Islam in Africa constitute a force that hinders the spread and expression of homosexuality, due to what Yip ${ }^{27}$ calls "the shackles of religion that upholds moral absolutism and a heteronormative power structure". It is out of realistic representation that homosexuality is not openly discussed in African writing, African gays, lesbians and bisexuals exist under the cover of masks for fear of public victimization and opprobrium in both imaginary and material world. However, Ben Jelloun manages to address explicitly and implicitly the queer question of transgressive sexuality in his writing.

\section{HETEROSEXUALITY, HOMOSEXUALITY AND BISEXUALITY}

Like all works of literature, Ben Jelloun's travel writing demonstrates a predominantly heterosexual society where men and women are found in existential relationship and its patrilineal family structure. Fathma has her father and mother in Les Yeux baissés, and she goes on to form her own family that disappears like the dream of the night. Mohamed lives with his wife and five children in Au Pays. Of his offspring, Mourad and Jamila are married to Christians in France where they are born and bred. Wahida's polygamous father has with two wives before the death of her mother in Labyrinthe des sentiments and she is found in heterosexual relationships in Morocco and Italy. And Azel lives with his widowed mother and sister, Kenza in Partir. His sister is heartbroken by a failed relationship with her Turkish suitor, Nâzim before her return to Morocco where she remains single. In his mélange of fact and fiction, the writer does not shy away from the patriarchal configurations that define heterosexual relationship and the biological and religious gender paradigms that undermine womanhood, rendering some heterosexual marriages problematic. There are handful of cases of physical, artificial psychological divorces or abandons such as Fathma's and Slima's, Soumaya's and Kenza's, and Wahida's. As regards these new generation migrants, none of the novels presents love as successful, life- 
affirming element; love is made impossible in each narrative in part through what Mooney calls "censoring mediations with sexuality"28. The heterosexual union of Kenza and Miguel is a negotiated or arranged marriage for Kenza to migrate to Spain and for Miguel to seal his adoption deal of Moroccan twins, Halim and Halima. Though homosexual, the Spaniard Miguel accepts mock conversion to Islam, a condition for his mock marriage to Kenza. Such a phenomenon characteristic of African migrants/immigrants to/in Europe dismantles the cultural and religious sacrosanct hegemony of heterosexual marriage that is challenged in most societies by transgressive sexualities.

Homosexuality and sodomy are common in Muslim Spain called Andalusia and the Maghreb is known to have strong ideological and demographic links with it and that explains its history of male homosexuality, according to Daniel Eisenberg ${ }^{29}$, especially as it concerns "male youths and slaves who took 'passive feminine' sexual roles" ${ }^{\prime 3}$. Homosexuality, lesbian or gay, suffices in African and Maghrebian literature in warrant an insight of analysis. Angèle Rawiri ${ }^{31}$ shows sketches of lesbian relationship between Emilienne and Dominique in Fureurs et cris de femmes which could be seen as a product of homosexual orientation not of behavior. Stephen Murray $^{32}$ has made an ontological distinction of both terms commonly used in gay discourses. Emilienne's psychological trauma occasioned by denials of heterosexual exigencies orientates her towards homosexuality as she seeks refuge in Dominique's feminine touches. In Beyala's writing, she uses lesbianism to deconstruct masculinity and to proclaim what Mary Louise Pratt calls Feminotopia ${ }^{33}$. The Cameroonian diasporic writer unveils the lesbian orientation of her character, Ateba in C'est le Soleil qui m'a brûlée $e^{34}$. Like Beyala, Ben Jelloun shows sketches of homosexuality in his writing.

In Les Yeux baissés, Ouzgane acknowledges that sexuality is associated with colonial experience, through the story of Abbas, the homosexual community Caïd who was used by the colonial masters to dispossess the village the source of water for their irrigation and agriculture. Mohamed knows that "Abbas n'aimait pas les femmes...Il recevait des garcons la nuit" 35 [Abbas did not love women...he was receiving boys at night]. To kill him and bring back the community source of water, Mohamed poses like one of his passive partners at hours of darkness. Homosexuality is seen as the exotic Other, as Abbas by the virtue of his liaisons with the Whites, remains paradigmatic of exoticism. Miguel Romero Lopez, the Spaniard living in Morocco, is a gay of high repute who, apart from Azel and other Moroccans, has also Brazilian homosexual partners in Partir. Miguel describes the genesis of his homosexual tendency and life and how he suffered from his catholic parents. In his Spanish home, those gay men collaborate with Miguel to curse Azel after his homosexual intercourse with a man-woman homosexual. Another European gay is Jean Genet, the imaginary character/French writer. Though Azel plays the passive role for Miguel's homoerotic pleasure, he can be rather classified as a bisexual character.

Bisexuality as a form of ambivalence that now characterises human society. Sexual ambivalence is widespread in African literature, caused by social and economic conditions that produce the fluid and unstable identities of characters. Emilienne in Rawiri's Fureurs et Cris de femmes, Irene in Beyala's Femme nue femme noire $^{36}$, Ateba in C'est le Soleil qui m'a brûlé and host of other literary figures are examples of ambivalent sexuality and sensibility. Paradigmatic of these characters is their oscillation between heterosexuality and homosexuality that gives them bisexual identities.

By definition, a bisexual experiences sexual desire for persons of both sexes ${ }^{37}$. The bisexual orientation of Angèle Rawiri's Emilienne is psychologically motivated while Ateba with Irene in C'est le Soleil... and Irene with Eva (Hayatou's wife) are in lesbian relationship occasioned by homosexual behavior or gay orientation like in the open copulation of Hayatou and Félix in Femme nue femme noire. This confirms the fact that bisexuality is becoming a leitmotif in African literature and it is also a sexuality reality in the Moroccan society painted by Ben Jelloun in his Partir.

Azel copulates with Miguel as a gay partner at the same time with Siham and Soumaya as heterosexual partners. His homosexual orientation towards the Spaniard demonstrates how socioeconomic forces can construct a new sexuality. This well-defined relationship with Miguel remains a bridge through which Azel migrates to Spain, constructed as his "promised land". This young Moroccan lawyer suffers complete rape from the Moroccan police while in detention and partial rape from Miguel gay friends. Dressed as a woman, he displays to the pleasure of Miguel's gay group, yet thinking of his girlfriend Soumaya. The narrator summarises his sexual ambivalence in this manner: "Il couchait avec Miguel mais trouvait son plaisir avec les femmes" 38 [he slept with Miguel but found his pleasure with women]. Like the two policemen that raped him, Azel oscillates between genders, so can be called a bisexual. Bisexuality is only part of other sexual transgressions that categorise Maghreb as a sotadic zone ${ }^{39}$.

\section{Morocco As Richard Burton's Sotadic Zone}

Richard Burton as a travel writer and translator used 'sotadic zone' to map and contest sexualities. Though problematic and polemical, his sexual geography emanates from his translation of Nights and lays emphasis on the phenomenon of pederasty in his sexualised zone. Burton's sotadic zone "is precisely bounded, 
with imaginary walls that seem to keep pederasty in, to contain this and other deviant but just-repressible desires and sexual acts...Like the walls of zoo, they contain all sorts of animal passions, which are fascinating but dangerous" "40. In his article, 'Writing Travel and Mapping Sexuality: Richard Burton's Sotadic Zone', Phillips argues why Burton's sexuality and geography are dynamic and open, manifesting an open disdain for the absoluteness of fixed points and rigid boundaries. His Sotadic Zone is characteristic and endemic of sexual transgressions such as pederasty, homosexuality, prostitution, bestiality, debauchery, and erotic perversion, propelled by 'animal passions' inherent in the zone. Morocco, geographically situated in this zone, appears to manifest such characteristics in Ben Jelloun's writing.

Partir is interlaced with the obsession for migration and culture of feminine prostitution, in home (Siham/Khaddouj's ring) and abroad (Soumaya, Nigerian and Moroccan prostitutes). Only few ladies and girls such as Kenza and the petite Malika are free from commercial traffic of body but not free from economic exploitation by employers of labour. They are gainfully employed though poorly remunerated. In addition to female prostitution, homoeroticism becomes so omnipresent that Azel is homosexually assaulted by police officers in a detention. In Les Yeux baissés, elements of pederasty and bestiality are weaved with threads of life. Though pederasty is related to under-aged boys, it manifests heterosexually by Hadj Brahim's desire to abuse an 11 year-old girl Fathma in a French public garden. Fathma, who escapes the grips of a pedophile, narrates also the witnessed sexual abuse of a goat by Rahou, an elder son of their neighbor in the village. This horrifying bestiality confirms Burton's claim of transgressive sexuality in Morocco, existing with homosexuality and unparalleled eroticism.

\section{Exegesis Of Eroticism}

Though exegesis and hermeneutics as critical interpretation and its principles are applied to the Bible or other sacred books, by exegesis of eroticism we intend to show Ben Jelloun's transgressive portrayals of eroticised male and female bodies as site and sight of contemplation and consummation, paradigmatic of European boundaries and borders that can be freely or forcefully penetrated. His eroticism receives an avalanche of criticism from a Maghrebian conservative religious society; critics should look beyond the veil of eroticism to bring out the authorial intention of eroticisation. In his writing, mainly Partir and Labyrinthe des sentiments, unlike most Maghrebian Muslim writers, Ben Jelloun publicises the private, says the unsaid and unveils the veiled, by his representation of the erotic.

In Labyrinthe des sentiments, both the linguistic and extralinguistic combine to invoke the erotic that materialises in the text through the marriage of opposing genres: drawing, letter writing, poetry and prose. All the artistic drawings present eroticised male and female bodies and their partes obscenae, that is the genitals, stamping some pornographic images only on the minds of readers. This dramatic irony eroticises the readership not the literary characters such as Wahida who only attains sexual arousals through the erotic words of Gharib's poems. The poetic words locate the soul and spirit of Wahida, causing her to undress, step by step, before the eyes of her lover. All the poems draw a paradigmatic relationship between women and pleasure. For example, the title "Les Femmes de Naples" eulogises the present-day Neapolitan women who love to enter into water undressed because men "aiment les voir sortir trempées, le chemisier collant à leur peau et les seins lourds de désir" ${ }^{41}$ [like seeing them come out of water soaked, blouse gummed to the skin and the breasts heavy with desire]. The novel names the erogenous zones of female body: "fesses" [buttocks], "pubis" [pubis], seins [breasts] to describe the naked body of Wahida in Laziz's bathroom, to describe an unprocessed body that Gharib cannot possess and evoke an appetising body that he cannot consummate either. He only contemplates and gazes at a naked body because "sight allowed rapid perception of objects and actions at distant horizons. The detached beholding sight allowed a deeper and more accurate apprehension of the reality of things" ${ }^{42}$ This eroticised unconsummated body metaphorises European landscape perceived from Moroccan high terraces where Moroccan youths stand to assuage their obsession for migration. This romanticising contemplation of Europe is more pronounced in Ben Jelloun's Partir.

The Mediterranean Sea and Atlantic Ocean separate Morocco from Europe. Morocco's proximity to Europe and Spain particularly creates this irresistible panoramic contemplation that becomes romantic, erotic and psychological in Ben Jelloun's Partir. The esplanade of Boulevard Pasteur which gives an aerial view of the sea provides Azel, the protagonist with this experience of amorous 'foreplay' through the contemplation of "les lumières de Tarifa". Aziel takes a promenade along the coastline; he watches the vessels embark and disembark, likes to listen to engine noise and shouts from sailors, and plunges into reveries. Like her neighbor Azel, Malika visits also this "terrasse des Paresseux" from where she observes the port and the Spanish coasts before going to school. If Labyrinthe des sentiments describes erotically unconsummated female body, Partir displays acts of lovemaking and its intrigues in order to show the possible possession and pleasure of/from female/male bodies.

Miguel's homosexual relationship is facilitated by the sight of Azel's half-covered body that reveals "la candeur de ce visage et la beaute de ce corps ou des hematomas etaient visibles" 43 [the guilelessness of this face and the beauty of this body with bruises]. Though Miguel only consummates this body in Spain, the police 
officers carry out a conspiratorial rape of Azel's male body in detention, for they told him: “T'es mignon" [you are lovely]. In Azel's sexual relationship with Siham, she decides from where he penetrates her and names erotically all names of male and female sexual organs. However, it is Azel's mistress, Soumaya who makes him discover the heights of sexual gratification. The narrator comments that her sexual wildness and expertise are unparalleled:

Soumaya n'avait aucune pudeur, aucun tabou, et se donnait sans rien dissimuler de sa passion pour ce qu'elle appelait "le vice". Elle avait une façon particulière de passer langoureusement sa langue sur tout le corps d'Azel, s'attardant toujours plus longuement entre les jambes et sur ses fesses. $^{44}$

Soumaya had no sense of decency, no taboo, and offered herself hiding nothing of her passion which she described as vicious. She had a particular way of languorously running her tongue through Azel's body, always waiting longer in-between his legs and buttocks.

The character is highly libidinous whose sexual experience enables Azel realise some erotic prowess. Like Siham, Soumaya's erotic knowledge gives a lasting impression and pleasure to the inexperienced Azel. She is emblematic of a liberated Moroccan woman whose eroticism pronounces her subjectivity and individuality, confronts sexual hegemony of masculinity and undoubtedly asserts her freedom from perennial silence of Maghrebian womanhood. Eroticism is partly attenuated in Ben Jelloun's writing, compared to the Cameroonian diasporic writer Calixthe Beyala who lives no stone unturned in her brutal description of sexual acts. Like Soumaya, Irene Fofo in Femme nue femme noire, Ateba in C'est le Soleil qui m'a brulée and other female characters in her novels are erotically wild. Ben Jelloun is distinct in that his characters' transgressive sexuality leads unfortunately to a transgressive spirituality.

\section{Spirituality Of Migrant Subjects}

In Ben Jelloun's representation of home and exile, spirituality appears to be a burning issue that cannot be neglected because of its relationship with femininity and masculinity. Though criticised or acclaimed for his audacity in penetrating restricted thematic zones such as sexuality and spirituality, the Moroccan diasporic writer does not strive to circumvent the authority of Holy Quran, but queries its exegesis and hermeneutics as regards to interreligious and feminist worldviews, hence his Islam expliqué/Islam explained. In his four texts under consideration, there are two extreme poles that explain attachment to and departure from Islamism and its hegemony.

The Moroccan old generation such as Fathma's father and his wife in Les Yeux baissés and Mohamed and his wife in $A u$ Pays shows high spiritual sentimentality in exiles. As professing Muslims, they hold the tenets of their faith with unparalleled commitment despite contrary modern realities like xenophobic killings. For example in Les Yeux baissés, a handful of Maghrebian immigrants such as Djellali, Bensaha, Rezki, Mohand, and others are murdered in cold blood. Living in a diasporic community in a Christian France, these Maghrebian Muslims engage in religious activities. Fathma's family fasts during the Ramadan and people like Moh observe all five daily prayers missing none. Fathma's father is a model of practicing and professing Muslim who conservatively queries why her daughter keeps Christian friends and loses her morality in France; he never hesitates to declare: "Nous sommes des musulmans" [we are Muslims]. These Muslims even desire to construct their mosque if given permission by French authority and attribute constant raid of their quarters as Christian war against them. Mohamed in $A u$ Pays never compromises his faith in France. In short the novel opens with his prayer and reflections on his pilgrimage to Mecca.

Mohamed's religious consciousness and consecration is unveiled in his saintly reverence of the Holy Qur'an which "fut l'unique livre qu'il emporta avec lui le jour de son départ du Maroc" 45 [was the only book that he carried with him on the day of his departure from Morocco]. The reason is not unknown because "ce livre était tout pour lui, sa culture, son identité, son passeport, sa fierté, son secret" ${ }^{\$ 6}$ [this Book was all for him, his culture, his identity, his passport, his pride, his secret]. Like his friend Moha, Mohamed's life as a Muslim is a model; he does drink alcohol or smoke cigarettes either; he regrets that his children are not like him. Forty years in France, he remains unchanged unlike the new generation. Mohamed's children, like Fathma in Les Yeux..., Azel in Partir and Wahida in Labyrinthe des sentiments, belong to new generation of Moroccan immigrants whose adherence to Islamic beliefs is problematic and ambivalent.

Mourad, Rachid, Othmane, Jamila and Rekya are Mohamed's five children who are critical of Islam and its principles. Mourad's and Jamila's marriages to a Spanish woman and Italian man respectively confirm their loss of religious consecration and conviction; their allegiance shifts from religiosity to subjectivity and 
individuality, which is the quest for personal happiness. Despite the resistance of Mohamed, both of them take their destiny in their own hands. Jamila sees his father's opposition to her marriage and his religious conservatism as a sign of psychosis. And pointedly she says to Mohamed: "réveille-toi, ma vie c'est moi qui la décide" ${ }^{\text {"47 }}$ [wake up; I am the one who decides my life]. Like Abdel Malek who becomes Mike Adley, Rachid changes his name to Richard to the chagrin of Mohamed, his father. Though Wahida remains Wahida in Labyrinthe des sentiments, she has subjective spirituality like other characters such as Gharib, Sakina and Laziz. The characters smoke and drink excessively without adherence to Islamic principles. Wahida's spiritual ambivalence is located in her words:

Sais-tu que tous les matins je vais prier à l'église qui se trouve à l'angle de la rue, comme une chrétienne je me couvre la tête et je me mets à genoux devant Jésus et lui demande de m'aider à laver mes péchés, mes égarements, mes fautes, je prie en arabe et j'invoque Mohamed, Allah et tous ses autres

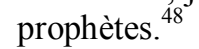

Do you know that every morning I go to the church located at the corner of the street, like a Christian I cover my head and kneel down before Jesus and ask him to help me wash my sins, my loss, my faults, I pray in Arabic and call on Mohamed, Allah and his other prophets.

Wahida's confessional statement amounts to betrayal of Islamic faith. Her adherence to two opposing religions appears problematic and preposterous, but however it reveals spiritual pragmatism and a transgressive spirituality which circumvents hegemonic theological structures to emphasise individualistic spiritual fulfilment over institutional religious conformity. Such spiritual phenomenon is facilitated through exilic experience of the migrant/immigrant who is influenced by the religiosity of the city of Naples, painted as wholly catholic with its monuments, cathedrals, and religious effigies. Like Wahida, Azel, Miguel and Kenza are characters whose spirituality is fluid and flexible in Partir.

Spirituality of Jellounian characters in Partir is highly politicised and desacralised ${ }^{49}$. Its fluidity enables the Christian, Miguel and Muslim, Kenza to enter into a mock Islamic marriage, programmed to disintegrate and dismantle at arrival to Spanish landscape, under the transgressive eyes of the Muslim Azel. The condition of this marriage is Miguel's conversion to Islam and his pronouncement of Chahada; he becomes Mounir. The objective of this charade is idiosyncratic and iconoclastic. It enables the two make-believe partners to take possession; Miguel seals his adoption deal of the Moroccan twins and Kenza relocates to Spain. Spirituality is negotiated and constructed as a means of any end. Through these images painted by Ben Jelloun, he ends up deconstructing religion, especially Islam and its hegemonic structures.

\section{Deconstruction Of Islamic Beliefs}

Ben Jelloun like Djebar seems to attribute women's oppression not just to endemic social customs, but to the entire structure of Islam, including its law, religion and culture. ${ }^{50}$ As a believing Muslim, he cannot question the relevance of Islam or call for its substitution with Western secularism but attempts to emphasise the need to rethink Islam and its beliefs in the face of contemporary realities. Jellounian reformism does not demand the holistic deconstruction of Islamic beliefs; rather it places emphasis on the need for better exegesis or hermeneutics of the Holy Quran to purge it of doctrinal ambiguities. The writer presents characters, passive and active, new and old generation, who are critical of certain beliefs and traditions of Islam as they live and work in exiles.

In $A u$ Pays, the Moroccan immigrant factor worker, Mohamed is acclaimed practicing Muslim whose undoubted commitment is evident in his daily life in France. Despite his uncompromising Islamic conviction, he thinks about his personal experience in his pilgrimage to Mecca where he suffered "de la promiscuité et de la violence de certains pèlerins." [from the promiscuity and violence of certain pilgrims] and wonder why his sandals were stolen by another pilgrim before the Great Mosque and why peoples are trampled mercilessly to death, abandoned on the ground and covered with dust and blood in their match around Kaaba. Mohamed's phobia for death in Mecca makes him think of alternative solitary tribal pilgrimage in spring. He equally criticises Saudi government for using Koran to justify inhuman treatments of peoples in their territory. Mohamed ends his criticism by underlining the need for religious tolerance. Though Bachir, his friend reminds him that a Muslim does not criticise what happens in Mecca, he affirms that criticisms are good for development. Unfortunately, Mohamed is indicted for religious tribalism; he only believes that "un musulman est arabe ou berbère" ${ }^{, 51}$ [a Muslim is an Arab or Berber]; others such as Africans, Chinese and Turks are not true Muslims. Despite his religious commitments, Mohamed's children do not approve of his conservatism. 
Mohamed opposes Mourad's and Jamila's marriages to a Spanish woman and Italian man respectively; both are Christians of European origin. His opposition is premised on his Islamic conviction/censure on/of interreligious marriage, yet the novel celebrates the triumph of individualism over institutionalism, pragmatism over conservatism, and liberalism over traditionalism. Jamila, though a Muslim by birth, reminds her father that the question of who to marry remains her exclusive right and has nothing to do with Islamic traditions. Ben Jelloun appears to sanction interracial and interreligious marriages as a means of enshrining and achieving global religious tolerance. Interracial marriage is seen as well in Labryinthe des sentiments where Gazelle's or Ghizlane's father, a Moroccan immigrant marries a woman of Naples, as narrated by Gharib.

In the discourse on Islamic injunction on (non)consumption of alcohol and ham, Wahida underlines some doctrinal ambiguities in the Holy Quran by telling Gharib that

11 existe dans le Coran deux versets contradictoires à propos du vin, l'un dit qu'Allah interdit aux musulmans des boissons qui ont fermenté; l'autre dit qu'il ne faut pas faire sa prière alors qu'on est ivre..$^{52}$

There are two contradictory verses in the Qur'an concerning wine, one says that Allah forbids Muslims from drinking fermented wines; the other says that it is not good to say prayers when one is drunk.

The interlocutor opines that this ambiguity "autorise sans l'autoriser la consommation du vin" [authorises without authorising it the consumption of wine]. It is possible to say that such "ambiguity" is not inherent in the Holy Quran, but emanates from exegesis and hermeneutics of the Book. However, it appears that the second verse reinforces the first verse of non consumption of wine. The consensus of the discursive engagement of Wahida and her friend Gharib is spiritual subjectivity and individuality because for them "tout ce qui est réligieux relève de la conscience de chacun" ${ }^{53}$ [all what is religious comes under individual conscience].

In Les Yeux baissés, the writer equally criticises the segregated gendered Islamic education. Girls such as Fathma have no right to attend the only Quranic School in the village. For obsession for education, she ends up impersonating his brother but receives the reprimand of a blind fqih who identifies the female intruder. The trope of impersonation or stimulation is not novel in Ben Jelloun's writing. In his La Nuit sacrée $e^{54}$, Ahmed/Zahra, a female child is raised as a boy who ends up presiding over/partaking in the funeral prayers of her/his father in the village mosque, against Islamic traditions. Ahmed who is later called Zahra breaks the Islamic hegemony and penetrates a religious space exclusively reserved to male Muslims. The writer appears to wonder why such gendered mapping of religious space which is patriarchal in nature. The deconstruction of Islamic beliefs entails the deregulation and demythologisation of Islamic space such as praying grounds and mosques, which favors Muslim women as a marginal group. In essence, inherent in Ben Jelloun's deconstruction of Islam is what is called today as Islamic feminism.

\section{Rhetoric Of Islamic Feminism}

All the women such as Fathma, Wahida, Kenza, Siham and others in our corpus "fight exclusion by forcing their way into the male-dominated public space and assert themselves as breadwinners by supporting their households, sometimes single-handedly"55. It shows that women are important in Ben Jelloun's contemporary travel writing because he recognises the positive role that Maghrebian women have been playing in the overall development of their countries ${ }^{56}$ and the need to dismantle all religious and cultural roadblocks on their way of self-realisation. Ben Jelloun's novels like the writings of Rifaat and Djebar espouse the need for the transformation of Muslim culture such that the practices of Muslims effectively harmonise with the teachings of the Quran, according to Nkealah ${ }^{57}$ who argues the integration of indigenous and Islamic cultures and distinguishes between Muslim and Islamic cultures. Islamic culture is spatially universal, based on the teachings of Koran and the Hadiths of the prophet and endorses the equality of rights for men and women whereas Muslim culture is spatially differentiated, refers to daily practices of Muslims and is patriarchal in nature. In an attempt to buttress the claim for a revised Islamic notion of gender relations (Hammed Shahidian), Ben Jelloun's writing illustrates the rhetoric of Islamic feminism.

Islamic feminism as a term assumes a discursive dimension since the 1990s because the Quran contains principles of gender equality and wider issues of social justice, thus laying grounds for challenging patriarchal traditions perpetrated through the interpretation of the Quran and Hadith. ${ }^{58}$ Barlas defines Islamic feminism as "discourse of gender equality that derives its mandate from the Qur'an and seeks rights and justice for all human beings across the totality of the public-private continuum"59. It is paradigmatic of Islamic modernism that popularises the practice of ijtihad, which is independent critical examination of religious texts, enabling the conduct of personal tafsir ${ }^{60}$. This Islamic feminist phenomenon is attributed to the group of progressive religious scholars called the "alems" and its result can be seen in the recruitment of first group of women 
religious mosque preachers by the Moroccan Ministry of Religious Affairs in $2005^{61}$, and in the successful application of gender equality in the 2004 revision of the Moroccan family law called al-Mudawwana whereby the two spouses become co-heads of the family. ${ }^{62}$ In such situation, polygamy becomes virtually impossible because married female Muslims can now initiate divorce proceedings.

In the world portrayed by Ben Jelloun in his writing, patrilineal family system is mirrored to reveal the dichotomy and polarity that exists between the new and old generations of Muslims, and the progressive youth and the conservative old of Islamic religion in the new modern dispensation. Such phenomenon generates religious conflicts of generation and crisis of conviction. The writer uses the ideologies of progressive female and male characters to reflect the rhetoric of Islamic feminism which constitutes the fabrics of his plot in L'Enfant de sable (1985) and La Nuit sacrée (1987), signaling the demystification of masculinity and phallocentrism in the Maghreb. Zahra's mother and six sisters are neglected and abandoned by her father Hajji, but she is raised up as a male child named Ahmed and enjoys all paternal privileges including inheritances from a father who wants a male child by all means. At the death of her father, Zahra is hunted by his uncle, raped by a stranger and migrates to another town where she sees sexual pleasure, persecution and imprisonment. Like Zahra, Fathma is born and bred in village where social infrastructures are nonexistent and where "il n'y a de loi que celle des hommes" [there is no law but that of men] in Les Yeux baissés. Staved of childhood education, she migrates to France with her father and acquires western education. Her academic records show a good performance. For her, Morocco is painted as a dream killer while Europe is represented as a dream booster. Like Fathma, Mohamed's girls are given equal rights to French education just like the boys in Au Pays.

Ben Jelloun demonstrates the capacity of women to acquire education in his novels in order to deconstruct the underprivileged marginal position of Maghrebian women enshrined in the political Islam and its patriarchal interpretation of the Holy Quran. It should be noted that French rule that gave birth to the Algerian, Moroccan and Tunisian nationalisms that in turn activated "political Islam" as they sought roots in Islamic as well as national identities ${ }^{63}$. In Labyrinthe des sentiments, Ben Jelloun neutralises the patriarchal marginality of womanhood by projecting firstly Wahida's mother as a breadwinner of her household and secondly Wahida who assume that position after the death of her mother. Self-sponsored through sexual trade, she ends up becoming a lawyer. Her refusal to practice law due to systemic and systematic corruption is an indictment of Maghrebian masculinity who orders a failed society. She belongs to a generation of female migrants to Europe to demystify the antifeminist primordial concept of "Angel of the Home", relegating women to private space of domesticity and passivity. Other women are Siham, Soumaya and Kenza in Partir who use all forms of whims and caprices to cross the borders for greener pastures.

Like Zahra and Wahida, these three women express their subjectivity through promiscuity and eroticism that is often initiated by them. Muslim women have been attributed to sexual passivity and domesticity, Partir portrays Soumaya, Siham and Kenza as sexually active and liberated. In most cases, they are initiators of sexual acts that are dominated by their sense of erotica. In addition, Siham and Kenza are equally gainfully employed both in Morocco and Spain. The appropriation of masculine landscape and language, as seen in migration and eroticism of female characters, cannot be without repercussion from a threatened masculine space. Wahida and Sakina are betrayed and sold in Labyrinthe... and Kenza and Soumaya are betrayed and abandoned respectively by their foreign suitors. Kenza ends up being eternally single and female right activist who tries "defender l'idée qu'on pouvait être célibataire et heureuse, libre et digne, respectée et aimée" defend the idea that one can be single and happy, free and worthy, respected and loved]. She is determined to carry out her campaign despite the ill-feelings of her patriarchal environment; it is believed that her life reflects a sort of bovarysm ${ }^{65}$. Like the activist Kenza, Fathma challenges the masculine hegemony at her matrimonial home where her husband, though a promoter of women rights, expects her to obey some cultural orders. She reports:

il me veut les yeux baissés comme au temps où la parole de l'homme descendait du ciel sur la femme, tête et yeux baissés, n'ayant pas de parole à prononcer autre que: "oui, mon seigneur!" Il appelle ça de la pudeur, moi je dis que c'est de la bassesse, de l'hypocrisie et de l'indignité. La pudeur, c'est regarder l'homme en face et confronter nos désirs et nos exigences. ${ }^{66}$

He wants my eyes lowered as at the time when man's words descended from heaven on woman, head and eyes lowered, having no word to pronounce other than: "yes, my lord!" He calls that modesty; I say that it is lowness, hypocrisy and indignity. Modesty is to look at man's face and compare our desires and our demands. 
Fathma's revelation circumvents Maghrebian Muslim culture of "les yeux baissés" promoted by patriarchal political Islam and 'smuggled' into Islamic culture that legitimises it as a transcendental moral law. She deconstructs this primordial antifeminist practice that others Maghrebian womanhood and is interpreted as sign of her modesty and meekness. Fathma declares the ontological death of this tradition by re-conceptualising modesty as the equality of rights of all sexes. Her feminist attitude explains the collapse of her marriage; she is abandoned by his man who declares his separation through a letter from home. His man is right to say that Fathma does not exist between liminal space of two worlds, but of third space "qui n'est ni ta terre natale ni ton pays d'adoption" [which is neither your land of birth nor your adopted country]. She desires a new world where women will assert their difference with indifference, to the detriment of patriarchal order. Though Fathma as the mythologised child of destiny in whose hands are placed the golden key of hidden treasure of her community, does not find the treasure, such position is a veneration of womanhood through mythology.

\section{Conclusion}

From his perception of mythology and magic, it can be understood that Ben Jelloun is an intellectual and hyphenated writer whose sojourn in Europe does not becloud his senses on seemingly unrealistic realities characteristic of his Maghreb and that define his Maghrebianness. His writing marries social realities with magical realities, facts with myths, the natural and the unnatural, and the real characters and the fantastic. Les Yeux baissés and $A u$ Pays for example showcase this organised synchronism of the conventional and the unconventional, the urban and rural, the Western and the indigenous, and the black and the white, leading to cultural and social cacophony that explains the generic hybridity of magic realism and its works. Ben Jelloun paints reality showing different dimensions of life, known and unknown, visible and invisible, and rational and mysterious. ${ }^{67}$

In Les Yeux baissés, the writer presents an intermarriage of myth, magic and realism. The story of Fathma is weaved around the subtext of the hidden treasure whose key is engraved in her life. Though Ben Jelloun ends up deconstructing and neutralising the mythology that unveils a primordial ignorance and superstition by the impossibility of locating the treasure and the possibility of the discovery of water through communal efforts, he does not question the potency of magic that can create terror and tyranny. Slima, the sorceress and witch, represents the face of magic in the novel, consulted for spells and destructions. For vengeance, she uses her mysterious powers to kill Driss, Fathma's only brother in the village. Her wickedness is recognised by the supernatural character in the cemetery, who encourages Fathma's father to migrate. In $A u$ Pays, Mohamed cannot escape the bad omen that had been prophesied by a ghost-like character who advised him to forsake his palatial mansion constructed with his life savings in France. Filled with the illusion of a family reunion in his hometown, Mohamed refuses to elope with his wife despite the repeated warnings and irrationally mysterious signs and sounds in his costly house. This villa becomes haunted and cursed where mysterious things are happening to Mohamed's chagrin. He dies of mysterious and incurable sickness and is buried in the same village where he was born before his journey to France. From his life, the novel demonstrates an irony that is compromised, contradictory and corrosive, and the writer does not struggle to distance himself from such magical irony in order not to compromise its realism. ${ }^{68}$ Even in Partir where Azel's sudden impotency or what himself describes as Walou! Walou! is attributed to a spell from Carmen who had consulted Maria, an old seer, sorceress and spell caster in Spain, Ben Jelloun shows his reticence by respecting magic and not judging its veracity, efficacy and authenticity.

[1] Benmessaoud, Sanaa. “ Liberating Shahrazad: Feminism, Postcolonialism, and Islam”. Journalof International Women's Studies. Vol.11, No.2, November 2009, p.231-233

[2] Moukhlis, Salah. "Deconstructing Home and Exile: the Subversive Politics of T.B Jelloun's With Downcast Eyes." Postcolonial Text, Volume 2, Number 2, $2006<\mathrm{http}$ ://postcolonial.org/index.php >

[3] Okafor, Chinyere Grace. "La Littérature Africaine et le Beauvorisme: Exemple d'Action de Femmes et d'Ecrivains" Delphy, Christine and Sylvia Chaperon (eds.) Cinquantenaire du Deuxième Sexe. Paris: Syllepse, 2002, 259-268

[4] Etoke, Nathalie. "Writing the Woman's Body in Francophone African Literature: Taxonomy Issues and Challenges" CODESRIA Bulletin, Nos. 3 \& 4, 2006, 41-44

[5] Mooney, Susan. The Artistic Censoring of Sexuality, Columbus: The Ohio State University Press, 2008

[6] Sadiqi, Fatima. "Facing Challenges and Pioneering Feminist and Gender Studies: Women in Post-colonial and Today's Maghrib." African and Asia Studies. 7(2008), 447-470

[7] Sadiqi, Fatima \& Moha Ennaji. "The Impact of Male Migration from Morocco to Europe on Women: A Gender Approach." Finisterra, XXXIX, 77, 2004, 59-76

[8] Valentine, Gill. "Queer Bodies and the Production of Space." Handbook of Lesbian and Gay Studies. 2002. SAGE Publications. 9 Apr. 2010 www.sage-ereference.com/hdbk lgs/article no10.html

[9] Ben Jelloun, Tahar. Labyrinthe des Sentiments. Paris: Stock, 1999, p.70

[10] Ibid. p.80

[11] L. Ouzgane, 1997. Masculinity as virility in Tahar Ben Jelloun's work. Contagion: Journal of Violence, Mimesis, and Culture 4: 1-13.

[12] Ben Jelloun, Tahar. Partir. Paris: Editions Gallimard, 2006 
[13] Benmessaoud, Sanaa. “Liberating Shahrazad: Feminism, Postcolonialism, and Islam”. Journal of International Women's Studies. Vol.11, No.2, November 2009, p.232

[14] Op. cit., p.75

[15] Ufford, Ikike Inieke. "Personality, Feminism and the Nigerian Woman in Ahmed Yerima's The Portrait." Atakpo, Uwemedimo \& Stephen Inegbe (eds.) Making Images, Re-makingLife: Art and Life in Ahmed Yerima. Nigeria: Modern Business Press, 2007, 196-208, p.198

[16] Sambou, Ephrem. "La Sexualité dans le Pleurer Rire d'Hénri Lopes." Ethiopiques. No. 81, "Littérature, Philosophie et Art", Deuxième semester, 2008. www.ethiopiques.com/

[17] Ben Jelloun, Tahar. Les Yeux baissés. Paris : Editions du Seuil, 1991.

[18] Ben Jelloun, Tahar. Au Pays. Paris: Editions Gallimard, 2009

[19] Mojola, Yemi. "Women as Axe-men of Womanism in the Works of Selected Francophone Female Novelists of West Africa." Ade Ojo, Sam \& Olusola Oke (eds.) Themes inAfrican Literature in French. Ibadan: Spectrum, 2000, 243-260, p.243.

[20] Ben Jelloun, Tahar, Les Yeux, pp.297-8

[21] Ibid. 298

[22] Ibid. 296

[23] McKenna, Wendy \& Suzanne Kessler. "Transgendering: Blurring the Boundaries of Gender." Handbook of Gender and Women's Studies, 2006. SAGE Publications. 9 April. 2010. http://www.sage-ereference.com/hdbk.genderstudy/Article n20.html.

Morgan David. "The Crisis in Masculinity." Handbook of Gender and Women's Studies, Sage Publications, 2006.9 April, 2010 www.sage-ereference.com/hdbk.genderstudy/Article n7.html

[24] Nathalie Etoke, Op.cit. p.43

[25] Anderson, B. The politics of homosexuality in Africa. Africana 1.1 (2007):123-136, p.126.

[26] Yip, Andrew. "Religion and the Politics of Spirituality/Sexuality: Reflections on Researching British Lesbian, Gay and Bisexual Christians and Muslims." Fieldwork in Religion (FIR). Vol. 1, No. 3 (2005): 271-289, p.275

[27] Mooney, p.273

[28] Eisenberg, Daniel. “Juan Ruiz's Heterosexual 'Good Love'.” Queer Iberia. Gregory Hutcheson\& Josiah Blackmore (ed.), Duke University Press, 1999, 250-74

[29] Drucker, Peter. "In the Tropics There is no Sin: Sexuality and Gay-Lesbian Movements in theThird World." New Left Review, 218, 1996, 75-101, p.76

[30] Angèle Rawiri. Les Fureurs et cris de femmes. Paris : L'Harmattan, 1989.

[31] Stephen Murray. "The comparative sociology of homosexuals." Handbook of gay and lesbian studies, Sage Publication. 2002.

[32] Mary Louise Pratt. Imperial eyes. London: Routledge, $2^{\text {nd }}$ Edition. 2008, p. 163

[33] Beyala, Calixthe. C'est le Soleil qui m'a brûlée. Paris: Stock, 1987

[34] Ben Jelloun, Tahar. Les Yeux, p.176

[35] Beyala, Calixthe. Femme nue Femme noire. Paris: Albin Michel, 2003

[36] Mathews, Joan. "Bisexuality in the Male." The Journal of Sex Research. Vol. 5, No. 2, May 1969, 126-129, p.126

[37] Ben Jelloun, Partir p.126

[38] A zone bounded westwards by the northern shores of the Mediterranean (N.Lat.43\%) and by the southern (N.Lat.30\%). Thus the depth would be 780 to 800 miles including meridional France, the Iberian Pennisula, Italy and Greece, with the coast-regions of Africa from Morocco to Egypt. For further reading (Duncan \& Gregory (eds.) Writes of Passage, 1999)

[39] Phillips, R. "Writing travel and mapping sexuality: Richard Burton's sotadic zone." Writes of passage. Eds. J. Duncan \& G. Derek. London: Routledge. 1999.70-91, p.74.

[40] Ben Jelloun, Labyrinthe, p.64.

[41] Hurlbut, William B. "Mimesis and Empathy in Human Biology." Contagion. Vol.4, Spring 1997, 14-25, p.16.

[42] Ben Jelloun. Partir, p.56.

[43] Ibid. p.134.

[44] Ben Jelloun, Au Pays, p.17.

[45] Ibid. p.17

[46] Ibid., p.125.

[47] Ben Jelloun, Labyrinthe, p.96

[48] We use the term to mean to render unsacred or profane (see Mounia Benalil Protée, Vol.35, No.2, 2007, 95-104

[49] Nkealah, N. E. "Islamic culture and the question of women's human rights in North Africa: a study of short stories by assia Djebar and Alifa Rifaat." MA Thesis, University of Pretoria. 2006

[50] Ben Jelloun. Au Pays, p.11.

[51] Ben Jelloun. Labyrinthe, p.47.

[52] Ibid., p.47

[53] Ben Jelloun, Tahar. La Nuit sacrée. Paris : Editions du Seuil, 1987.

[54] Sadiqi, Fatima \& Moha Ennaji. "The Impact of Male Migration from Morocco to Europe on Women: A Gender Approach." Finisterra, XXXIX, 77, 2004, 59-76, p.67.

[55] Sadiqi, Fatima, p.447.

[56] Nkealah, 2006

[57] Kynsilehto, Anitta (ed.) Islamic Feminism:Current Perspectives. Finland: Tampere Peace Research Institute, Finland: Tampere Peace Research Institute, 2008, 9-10 < www.uta.fi/laitokset/kirjasto/taju $>$

[58] Barlas, Asma. "Engaging Islamic Feminism: Provincialising Feminism as a Master Narrative" Anitta Kynsilehto (ed.) Islamic Feminism: Current Perspectives. (Ibid.) 2008, 15-24, p.18.

[59] Badran, Margot. "Engaging Islamic Feminism." Anitta Kynsilehto (ed.) Islamic Feminism:Current Perspectives. Finland: Tampere Peace Research Institute, 2008, 25-36, p.29 www.uta.fi/laitokset/kirjasto/taju

[60] Eddouada, Saiad. "Implementing Islamic Feminism: The Case of Moroccan Family Code Reform." Anitta Kynsilehto (ed.) Islamic Feminism: Current Perspectives. Finland: Tampere Peace Research Institute, 2008, 37-46, p.40.

[61] Barlas, p.33.

[62] Henry, Clement. "The Dialectics of Political Islam in North Africa." Middle East Policy. Vol.XIV, No.4, Winter 2007, 84-98, p.85.

[63] Ben Jelloun, Partir, p.308. 
[64] The term bovarysme/bovarysm emanates from Gustave Flaubert's classic Madame Bovary (1857) where the protagonist Madame Bovary lived an imaginary life that brought her ruin, life influenced by novelistic ideas.

[65] Ben Jelloun. Les Yeux, p.274.

[66] Cooper, Brenda. Magical Realism in West African Fiction. London: Routledge, 1998, p.32

[67] Ibid., p.34. 